\title{
Role of Entrepreneurship in Future Economic Development of Taiwan
}

\author{
Mahendar Kumar \\ Independent Researcher, Graduate of Siam University, Bangkok, Thailand \\ Email: mahendarkumar580@gmail.com
}

Received 29 August 2015; accepted 10 October 2015; published 13 October 2015

Copyright (C) 2015 by author and Scientific Research Publishing Inc.

This work is licensed under the Creative Commons Attribution International License (CC BY). http://creativecommons.org/licenses/by/4.0/

c) (i) Open Access

\begin{abstract}
Historically, entrepreneurship played a central role in the economic development of Taiwan. Therefore, small and medium sized enterprises are considered a backbone of the Taiwanese economy. The purpose of this study is to elaborate the role of small and medium sized enterprises (SMEs) in terms of non-technical innovation of SMEs, human resource productivity of SMEs and government policies regarding SMEs in the future economic development of Taiwan and to analyze the SMEs role in terms of its social and economic impact and finally to produce conclusive statements based on the final observations. This research is based on transaction cost theory and it was conducted in Bangkok, Thailand. The research is qualitative with an inductive approach in nature. Final findings were based on five observations; the first three observations showed that there was a definite relationship between non-technical innovation, human resource productivity and government policies regarding SMEs with the future economic development of Taiwan and the remaining mentioned that the annual sales share of SMEs in Taiwan was only $30 \%$ in 2012 and export sales share was only $17.74 \%$; but on the social front, SMEs accommodated more than $\mathbf{7 9 \%}$ of workforce in Taiwan. These observations are combined to produce final statement of this research.
\end{abstract}

\section{Keywords}

Entrepreneurship, Economic Development, Non-Technical Innovation, Human Resource Productivity

\section{Introduction}

This study explains the roles of non-technical innovation, human resource productivity and government policies with respect to small and medium enterprises (SMEs) and their relationship with the future economic develop- 
ment of Taiwan. It also elaborates the role of human resources and how government policies facilitate the economic development of Taiwan. Taiwan ranks as one of the innovation-driven economies in East Asia and that innovation is mostly associated with SMEs in Taiwan [1]. So this study will predict the future effects of entrepreneurship on the economic development of Taiwan in terms of its innovation capacity and capability, productivity and government policies. This study has an important role to play in the formulation of government policies and decision making at the organizational level because SMEs are considered to be a backbone of the Taiwanese economy so their future role could be a decisive factor for the continued economic development of Taiwan.

The successful development of Taiwanese small and medium-sized enterprises (SMEs) has become the most important part of Taiwan's economic legend. Taiwan experienced spectacular development with rapid growth as well as an ongoing transformation from a traditional agricultural-oriented to a modern industrial and serviceoriented economy [2].

The intention of this study is to explore the relationship between the characteristics of entrepreneurship with the future economic development of Taiwan. Economic development usually refers to the adoption of new technology, skills and business processes in order to improve production facilitates and move from one economic stage into another that produces an important effect on the life of people in that country [3]. According to economics, there are three main economic development stages, namely: factors-driven economy, efficiency-driven economy and innovation-driven economy [4]. According to the global competitive index report 2012-2013, Taiwan is ranked as an innovation-driven economy because of the fact that Taiwan has high educational standards and the adaptation rate of new technology and sophisticated business processes are also appreciable. Taiwan attained $13^{\text {th }}$ position in the index, showing Taiwanese intellectual capability and capacity for innovation and adaptation of new technology [4]. The main pillar of Taiwan's economy was the production capacity of small and medium sized enterprises (SMEs) that played a vital role in the economic success of Taiwan in the past [5]. The word "entrepreneurship" literally means "to take or carry between" in the sense of economic transaction [6]. Ahmad and G. Seymour (2008) argued that entrepreneurship was a phenomenon of entrepreneurial activity [7]. The journey of SMEs in Taiwan started after the Second World War when each country started to place more value and importance on venture capital [8]. The global arena was created and globalization became fundamental to each and every economy [8]. At that crucial time period, Taiwan produced "black hand bosses" who were supposed to be the key players in the Taiwanese economy [9]. Black Hand bosses were those people who had skills, practical experience and enough social networking skills to start their own business. Surprisingly, the wives of those bosses also played a crucial role in the success of the Black Hand bosses [9].

This study will cover three elements of entrepreneurship, namely: non-technical innovation, government policies regarding SMEs and human resource productivity, and it will define their contribution to the future economic development of Taiwan. This study has limitations in terms of data usage, financial resources and the researcher's exclusive dependence only on secondary data regarding the subject at hand. The objectives of this research are to find out the relationships between non-technical innovation, human resource productivity and government policies with regard to SMEs and the future economic development of Taiwan and to understand the social impact and economic impact of SMEs and then to make a final conclusive statement.

\section{Statement of Problem}

Taiwan SMEs were considered to play a significant role in the past economic development of Taiwan as the data showed that export share of SMEs in 1980s was 68\% but later on, it reached 49\% in 1997 [9]. SMEs accommodated large number of workforce in Taiwan and the trend was continuing but government also played a key role in boosting and promoting SMEs in the past [9]. This study will predict the role of SMEs in terms of entrepreneurship in future economic development of Taiwan as the economy has been developed from an agricultural economy after Second World War into an innovation driven economy.

\section{Literature Review}

According to Robert Solow (1956), neo classical theory for economic development, it states that productivity growth takes place when there is disequilibrium between labor-capital ratios. As the capital per worker increases, it decreases the marginal productivity of that capital and ultimately there is no benefit to investment because capital-labor ratio is constant. Then technological progress plays its role and progress happens [10]. Economic 
development is mostly characterized by increasing gross domestic product GDP in nations and GDP per capita [11]. It also means the distribution of income [12]. Economic development ideally refers to the sustained, concerted actions of communities and policymakers that improve the standard of living and economic health of a specific locality [13]. The terms "economic development" and "economic growth" are often used interchangeably but in fact there is a very big difference between the two. Economic growth can be viewed as a sub category of economic development [14]. When social mobilization increases expectations and ambitions, economic development increases the capacity of society to satisfy their ambitions and therefore should tend to reduce social frustrations and any resulting political instability [15]. Economic development can also be referred to as the quantitative and qualitative changes in an existing economy [16]. Economic development involves development of human capital, increasing the literacy ratio, improving important infrastructure, improvement of health and safety and other areas that aim at increasing the general welfare of the citizens [16].

The development of Taiwan's economy can be characterized by structural change in favor of more capitaland technology-intensive industries as well as the continued upgrading of the economy in general and these industries in particular [2]. Taiwan has been an economic success since 1992; Taiwan's GDP growth has averaged 4.5 percent. This raised real per capita income from \$9116 in 1992 to \$19,762 in 2012, with the result that today Taiwan is the 28th wealthiest country globally, and 6th richest country in Asia. In addition, along the way Taiwan has transformed itself from a dictatorship into a vibrant democracy [17]. Fuelling this growth in Taiwan has been a rapid expansion in international trade. In 1992, Taiwan's total trade was over $\$ 180$ billion and represented 82 percent of GDP. In 2012, Taiwan's trade represented 140 percent of GDP and was valued at over \$650 billion, making it the world's 19th largest trader even though it is only the 28th largest economy in the world [18].

This study has used transaction cost theory which is also called "Theory of the Firm" by Ronald Coase (1937) in order to elaborate the role of entrepreneurship in the future economic development of Taiwan. This theory mainly claims that firms exist not because of carrying out the functions of production, marketing and distribution of goods and services on a large scale but that firms exist because of the internal transaction costs of carrying those operations are less than the outside world where this is defined by Coase (1937) as "It began to be seen that there was something more important than the relations inside each factory or unit captained by an undertaker; there were the relations of the undertaker with the rest of the economic world outside his immediate sphere.

The main points of why firms exist are defined by Coase (1937) as follows:

1) The less the costs of organizing and the slower these costs rise with an increase in the transactions organized;

2) The less likely the entrepreneur is to make mistakes and the smaller the increase in mistakes with an increase in the transactions organized;

3) The greater the lowering (or the less the rise) in the supply price of factors of production to firms of larger size [19].

The Taiwan economic success is obviously related to the effective and efficient institutionalization that has been inherited by the Taiwanese government and it played a crucial role in economic development of Taiwan [20]. "What gets measured gets managed" is an axiom in the business world [21] This is perfectly followed by Taiwanese entrepreneurs through reducing their transaction costs of information sharing, contract implementation and uncertainty cost, as argued by Williamson (1985) and Coase (1937) who empirically demonstrated that transaction cost minimization can help explain industry structure and decision-making by economic agents in the context of market transactions [22]-[26]. Taiwan's emergence as a newly industrialized nation is not just a miracle but it is evidence of how socio-economic bondage and thinking can change the fate of the country which is also illustrated by the researcher through this research. This is argued with the statement: "Better to be the head of a chicken than the tail of an ox" which describes this feature of Taiwan's ideology, especially in the business field. Such thinking drives machinists or apprentices to create their own businesses and become "black hands" bosses. These individuals, instead of learning from school, learned their skills through apprenticeship within factories. They learn by doing. Combining skills and experience, "black hands" set up their own businesses and creates opportunities for success [9].

Taiwan is not accepted as a sovereign state by the international community and it somehow hinders economic growth and development of Taiwan as argued by Riegl (2014) who claims that lack of international recognition and international isolation prevents unrecognized states from joining the ranks of sovereign states, as the world's most exclusive political club, and thus cannot enjoy all the benefits of political and economic globalization [27]. An unrecognized state is defined by Pegg (1998) as "places that don’t exist in international relations" [28]. 
Economic development today involves far more than just traditional manufacturing industry; the key drivers of growth for Taiwan in the future will be the innovation economy and environmental protection-related demand. The last few years have seen a pronounced trend towards the formation of multilateral and bilateral free trade agreements (FTAs) and comprehensive economic partnership agreements (CEPAs) within the Asia region. Taiwan cannot afford to isolate itself from this trend. The fifth "Chiang-Chen Meeting" saw the signing of the Economic Cooperation Framework Agreement (ECFA), marking the beginnings of a mechanism for free trade between Taiwan and China. On September 22, 2011 Taiwan signed a Bilateral Investment Agreement (BIA) with Japan, covering the three key areas of investment promotion, investment protection and investment liberalization. Also, the Trans-Pacific Strategic Economic Partnership Agreement (TPP) was a major focus of discussion at the Asia-Pacific Economic Cooperation (APEC) can help Taiwan to gradually secure fuller participation in the process of regional economic integration in East Asia [29].

The conceptual framework of this study (Figure 1) has followed the theory of the firm (1937) as its basis in order to explain the relationship between factors of entrepreneurship and future economic development of Taiwan. Then the researcher developed the following model and chosen three independent variables in order to define entrepreneurship. The research questions that would be answered through this research were whether or not there is a relationship between non-technical innovation, human resource productivity and government policies regarding SMEs with the future economic development of Taiwan and what is the overall economic impact of SMEs in the future economic development of Taiwan.

\section{Research Methodology}

This research is inductive qualitative research which used secondary data from different sources to analyze the research problem [30]. Inductive reasoning begins with specific observations and concludes with broader generalizations and theories [30]. This research is applied research because it was carried out to understand a particular business phenomenon and its effect on the future. As the applied research definition suggests "Applied research is done to solve specific, practical questions; for policy formulation, administration and understanding of a phenomenon. It can be exploratory, but is usually descriptive [31]”. The research has been carried out in natural settings and therefore it is non-contrived. The research has used qualitative data analysis software in order to analyze the data through coding and then applying text search and word frequency query at the end.

\section{Qualitative Data Analysis}

This research is carried out on the topic of the role of entrepreneurship in the future economic development of Taiwan and strived to answer three research questions related to this topic. As a matter of fact, entrepreneurship is an individualistic quality and it is linked with SMEs in Taiwan because most SMEs are sole proprietorship in

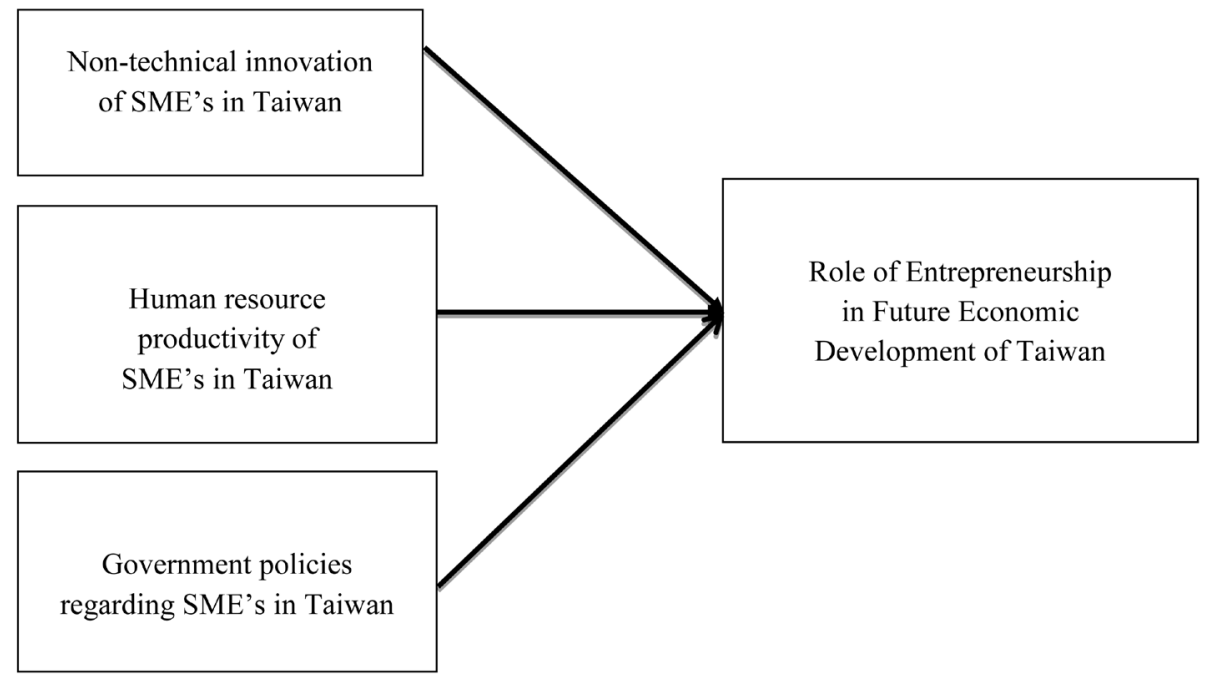

Figure 1. Conceptual framework of this study. 
Taiwan, therefore the most part of this research is done on the SMEs of Taiwan. The variables used to investigate entrepreneurship were non-technical innovation, human resource productivity and government policies. This research asked the following questions to be answered by the research process:

1) What is the role of non-technical innovations of SMEs in terms of entrepreneurship and its relationship with the future economic development of Taiwan?

In the pursuit to find the answer to this first question, the researcher has found immense data and literature that supported conclusions such as that economic growth can occur in two ways: 1) improvement in technical knowledge (neoclassical studies largely focus on this aspect of research), and/or 2) increased awareness of the availability of opportunities. Hence, economic growth occurs not only "because of the availability of new opportunities, but because of expanded awareness of existing opportunities" [32]. It is the job of an entrepreneur to exploit existing opportunities and create new opportunities as well. Innovation is considered a very important factor in the economic development of any country because organizational innovation actually decides the future of that country one way or another as Lin \& Chen (2007) argued, noting that innovation has been identified as the major factor in economic growth and the expansion of wealth and of an enterprise in the era of the knowledge-based economy depending on how it improves its organizational innovation capability. Porter (1990) described how companies achieve competitive advantage through acts of innovation [33]. Lin (2007) give the idea that innovation is the creation of new products, processes, knowledge or services, using new or existing scientific or technological knowledge [34]. This indicates that innovation is not only technical but includes non-technical innovation which complements and supplements the vast area of technological innovation as mentioned by Wu (2009) in which he says that "Non-technological innovation is an important element of companies' innovation activities that both supplement and complement technological innovation, i.e. the introduction of new products and new processes" [35]. His idea is reinforced by other scholars as well; innovation in firms is not just about developing and applying new technologies but also to adopt and re-organize business routines, internal organization, external relations and marketing [36] [37]. Non-technical innovation is considered to be innovation of business processes (mainly organizational innovation and marketing innovation). This is also mentioned by the Oslo manual (2005 Edition), "This non-technological character is reflected in the definition of the two new types of innovation introduced to the definition of innovation in the third (i.e. 2005) edition of the Oslo Manual. They are defined as follows:

"A marketing innovation is the implementation of a new marketing method involving significant changes in product design or packaging, product placement, product promotion or pricing [38].” An organizational innovation is the implementation of a new organizational method in the firm's business practices, workplace organization or external Relations" [38]. "Scholars have noted that SMEs are often more fertile than larger firms in terms of innovation [39]. Their comparative advantages over large firms in innovation are their flexibility and speed of response [40] [41]. As a result, SMEs generally make a valuable economic and social contribution because of their innovative capacities".

Along with this obvious and clear evidence, the researcher has found a link between non-technical innovation of SMEs and economic development of Taiwan by using Nvivo 10 software.

It was concluded by the two queries (namely word frequency and text search query through qualitative software Nvivo) that there is a definite relationship between the role of non-technical innovation of SMEs and the future economic development of Taiwan.

2) What is the role of human resource productivity of SMEs in terms of entrepreneurship and its relationship with future economic development of Taiwan?

The researcher found that there is a strong relationship between human resource productivity and the economic development of Taiwan, based on the fact that Taiwanese SMEs accommodate more than $75 \%$ of the total workforce in Taiwan. The researcher also concluded with other scholars like de Silva (1997) and (Becker et al., 1990) that human capital is an endogenous driver for economic growth and economic growth is necessary for economic development [42] [43]. Economic development implies the development of social, economic and political dimensions of a country, but economic growth is the key to achieve economic development as Rautakivi (2012) mentioned when claiming that economic development is mostly characterized by increasing gross domestic product GDP in nations and GDP per capita [11]. Economic growth boils down to three factors: capital, labour, and how they are used-i.e., productivity. While economists may have widely differing views on economic growth, they all agree on the importance of productivity. Strong and increasing productivity is vital to drive wealth creation and create a successful and sustainable economy. Capital is vital for any economy, partic- 
ularly at the early stages of development, supported by a growing and increasingly skilled labour force [44]. The researcher has also found that productivity of human resources is closely connected with the education system and skills development programs of any country as it was also confirmed by Ministry of Education report (2011) on Taiwanese education when it stated that:

“Taiwan's vocational education has actually provided a basis for human resource productivity in Taiwan from the last six decades and it does continue to play its role for the economic development of Taiwan” [45].

The researcher has also found that GDP per capita (PPP) is increasing and it implies that productivity is translated into GDP per capita as shown in Table 1 below.

The researcher has used two queries by qualitative software in order to reveal the relationship and role of human resource productivity of SMEs in the future economic development of Taiwan and concluded that:

There is a definite relationship between the role of human resource productivity of SMEs and the future economic development of Taiwan.

3) What is the role of government policies regarding SMEs in terms of entrepreneurship and its relationship with future economic development of Taiwan?

The researcher has found that government policies were central in entrepreneurship growth and development in Taiwan because without pro-SME policies, they could never have grown and prospered to this stage. This was also supported by other authors like the World Bank report (1994, 2002, and 2004) which stated that "The government policies actually determine the success and failure of SMEs because SMEs require external financial and legal support to compete and grow in the competitive environment”. This was also mentioned by Taiwan's Ministry of Economic Affairs in that "The emergence of Taiwan's SMEs is closely related to the economic, social and educational policies adopted by the government in the past: The 'Land to the Tiller' program and the Economic Construction Plan” [46]-[48].

The above transcripts and other scholars related with this subject supported the researcher's idea that government policies regarding SMEs have a relationship with and play a role in the economic development of Taiwan. Small and medium enterprises play a crucial role in the economic development of any country because they are easier to operate and individuals can groom their careers and financial stability through their solely-owned enterprises. Small and medium enterprises are central to economic development; they are the backbone of a country which wants to project itself as a fully developed nation with equitable socio-economic growth [49].

Table 1. Taiwanese GDP per capita (PPP) from year (1999-2011).

\begin{tabular}{lc} 
Year & Taiwan GDP per capita (PPP) \\
1999 & 16,100 \\
2000 & 17,400 \\
2001 & 17,200 \\
2002 & 18,000 \\
2003 & 23,400 \\
2004 & 25,300 \\
2005 & 27,500 \\
2006 & 29,500 \\
2007 & 30,100 \\
2008 & 31,100 \\
2009 & 32,000 \\
2010 & 35,700 \\
2011 & 38,200 \\
\hline
\end{tabular}

Source: Website Title, Index Mundi (http://www.indexmundi.com/g/g.aspx?c=tw\&v=67), last accessed 01 June 2015. 
Interestingly, 95\% of all registered firms across the world are SMEs, and the number is as high as 99\% for regions like Europe. Therefore SMEs play an integral role in fueling the progress of any country [49].

It is concluded by coding all data on the subject and analyzing it through Nvivo software word query and text search query that "There is a definite relationship between the role of government policies regarding SMEs and the future economic development of Taiwan".

Therefore, the analysis concludes that:

It is concluded by the two queries namely word frequency and text search query through Nvivo that there is a definite relationship between role of non-technical innovation of SMEs and the future economic development of Taiwan.

- Two queries (namely word frequency and text search query through Nvivo) revealed that there is a definite relationship between the role of Non-technical innovation of SMEs and the future economic development of Taiwan.

- Two queries (namely word frequency and text search query through Nvivo) revealed that there is a definite relationship between the role of human resource productivity of SMEs and the future economic development of Taiwan.

- Two queries (namely word frequency and text search query through Nvivo) revealed that there is a definite relationship between the role of government policies regarding SMEs and the future economic development of Taiwan.

\section{Conclusions and Discussions}

The final findings have achieved the four objectives of this study and the fifth objective is to produce a final statement based on the observations concluded by the final findings of the research. This research has found in previous section that there are enough qualitative data available to prove that there is a relationship between factors of entrepreneurship and future economic development of Taiwan. Moreover, following observations have been made to conclude the final statement of this research.

\subsection{Observation No. 1}

It was observed by the researcher that there is a relationship or there is a connection between non-technical innovation in SMEs and the role of entrepreneurship in the future economic development of Taiwan. This result concluded by using word frequency analysis and text search query in qualitative software. This can also be seen in the data used in this research e.g. "Scholars have noted that SMEs are often more fertile than larger firms in terms of innovation [39]. Pereira \& Romero (2013) argued that non-technological innovation is an important element of firms' innovation activities that both supplement and complement technological innovation. Some scholars have pointed out that innovation in firms is not just about developing and applying new technologies but also adopting and re-organizing business routines, internal organization, external relations and marketing [50].

\subsection{Observation No. 2}

It was observed by the researcher that there is a relationship or there is a connection between human resource productivity in SMEs and the role of entrepreneurship in the future economic development of Taiwan. This result concluded by using word frequency analysis and text search query in qualitative software. This can also be seen in the data used in this research e.g. the spirit of entrepreneurship among skilled employees which has led to the establishment of millions of SMEs that fulfill this dream. It is important to define the term human resources and productivity and then put them together in order to understand their collective meaning and implication [51] Becker et al., 1990 argued that human capital is an endogenous driver for economic growth and economic growth is necessary for economic development [42]. The researcher has found that the human resource productivity of SMEs plays a very important role in the economic development of Taiwan as argued by Chen (2003) who states that human resource development has historically made a large contribution to Taiwan's economic growth [52]. Furthermore, The Taiwanese economy has achieved its enviable labor market record by establishing policies conducive to the smooth functioning of labor markets. Supply and demand have largely been allowed to set wages and working conditions for Taiwan's work force [53]. The four East Asian NIEs [Hong Kong, Korea, Singapore, and Taiwan] are frequently grouped together in the literature. Indeed, we would note certain similarities about wage-setting institutions among these four economies [53]. 


\subsection{Observation No. 3}

It was observed by the researcher that there is a relationship or there is a connection between government policies regarding SMEs and the role of entrepreneurship in the future economic development of Taiwan. This result was concluded by using word frequency analysis and text search query in qualitative software. This can also be seen in the data used in this research e.g. East Asian and Latin American governments have an important role to play in supporting the economic development of SMEs across the region [54]. Entrepreneurial policies made by governments are essential for small and medium sized firms to become competitive in the internal and external environment in order to promote economic growth in the country [55]. The World Bank report (1994, 2002, 2004) stated that "The government policies actually determine the success and failure of SMEs because SMEs require external financial and legal support to compete and grow in the competitive environment” [46]-[48]. “The emergence of Taiwan's SMEs is closely related to the economic, social and educational policies adopted by the government in the past (The "Land to the Tiller" program and the Economic Construction Plan, MOEA, Taiwan) [29].

\subsection{Observation No. 4}

There is also evidence found in this research about the economic impact of Taiwanese SMEs in terms of its GDP portion which is less than 20\% (Figure 2), annual sales share (30\%) (Figure 3), and export sales share (17.74\%) (Figure 4) in 2012. Taiwan's economy mostly consists of the service industry (68.19\%) but Taiwanese SMEs do not feature strongly in the service industry (less than 10\%) in 2012. It was also found that most of Taiwan's workforce is dependent on SME operations. Therefore, the social cost of not supporting SMEs can be as high as 79\% of the total work force of Taiwan (Figure 5). The productivity index of Taiwan is also high-103.6 p in 2014 as compared to $99.37 \mathrm{p}$ in 2013. It is also a fact that most new organizations that are opened in Taiwan are SMEs with the ratio of SMEs to total enterprises increasing to 97.64\% (Figure 6) [56].

Taiwan SME GDP Contribution, 2012

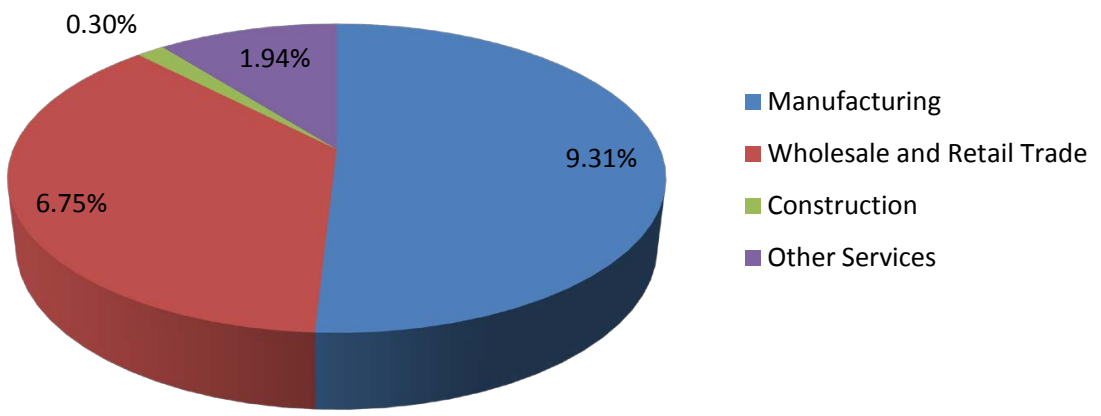

Figure 2. Taiwanese SMEs share in GDP-2012. Source: White Paper on SMEs 2012 issued by Small and Medium Administration, Ministry of Economic Affairs, Taiwan.

Comparison of Annual SME Sales to Large Corporations in 2012

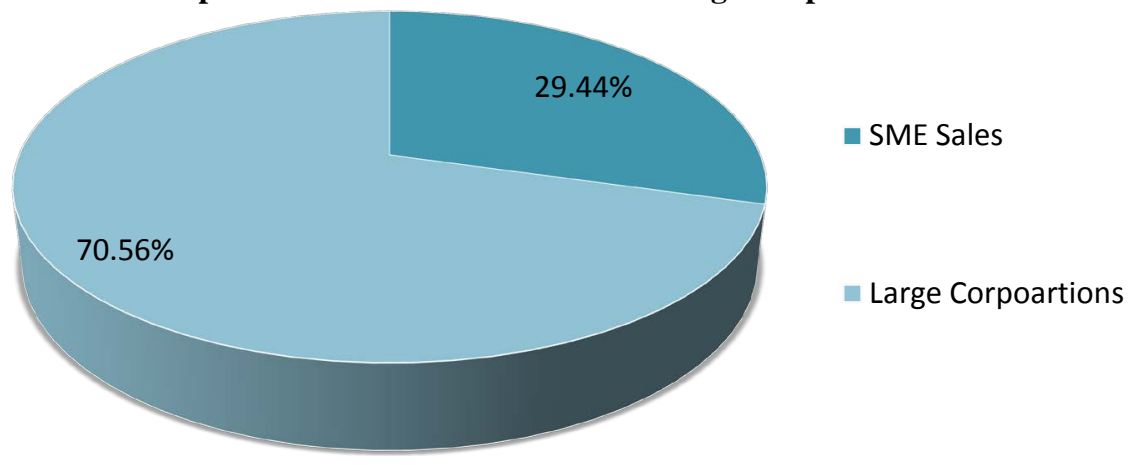

Figure 3. Taiwanese SMEs share of Annual Sales-2012. Source: White Paper on SMEs 2012 issued by Small and Medium Administration, Ministry of Economic Affairs, Taiwan. 
SME share of Export Sales to Large Corportions in 2012

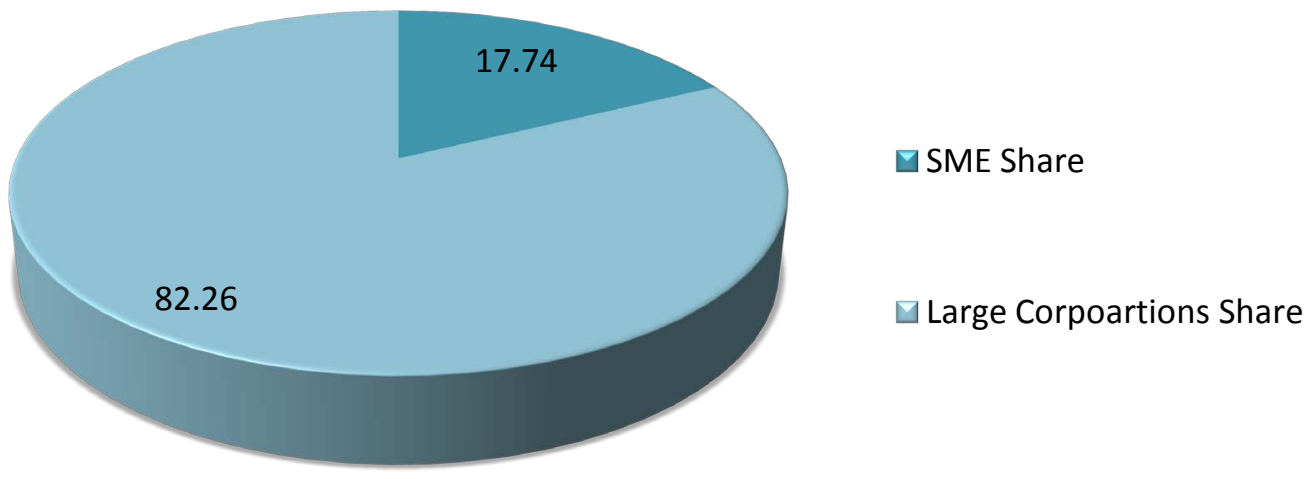

Figure 4. Taiwanese SMEs share of Export Sales-2012. Source: White Paper on SMEs 2012 issued by Small and Medium Administration, Ministry of Economic Affairs, Taiwan.

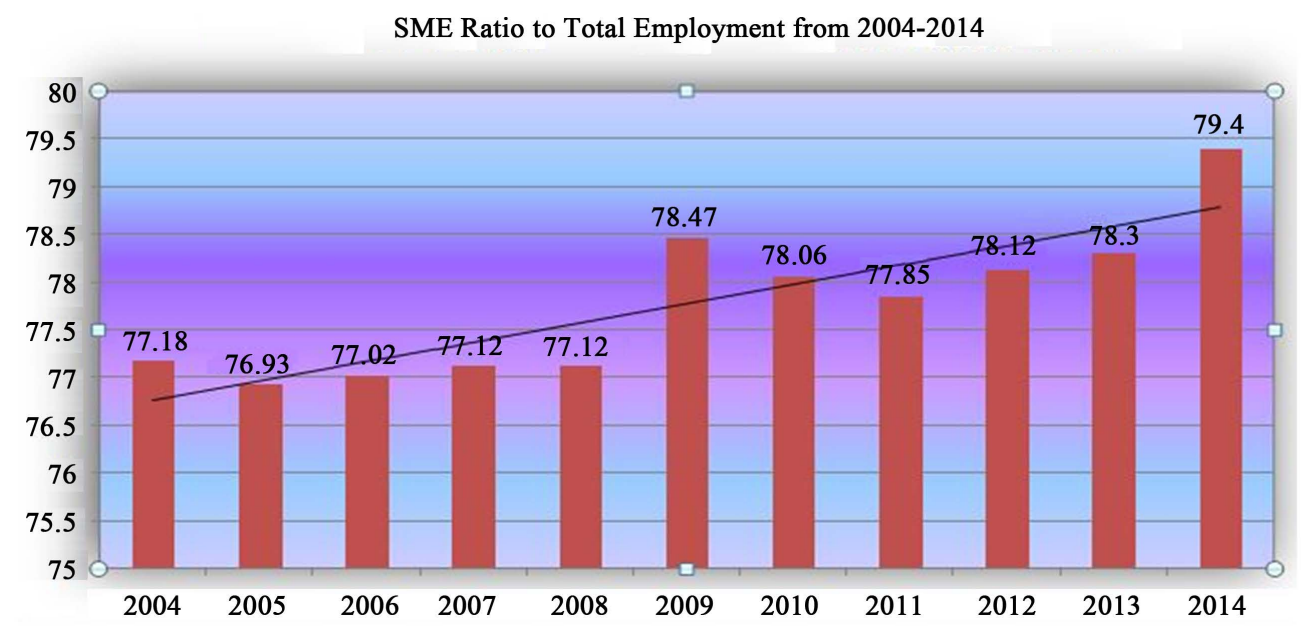

Figure 5. Taiwanese SMEs Ratio in Taiwanese overall workforce. Source: White Paper on SMEs 2012 issued by Small and Medium Administration, Ministry of Economic Affairs, Taiwan.

Taiwan SMEs share in Total Enterprises from 2004-2014

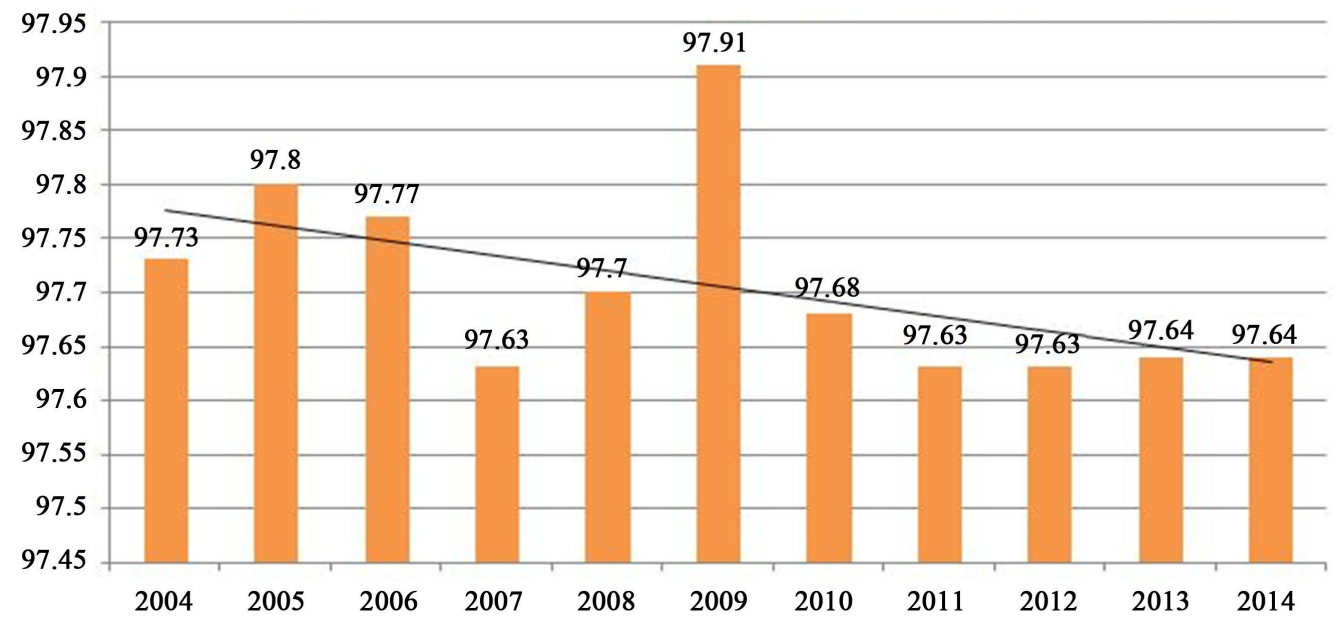

Figure 6. Taiwanese SMEs share in total enterprises (2004-2014). Source: White Paper on SMEs 2012 issued by Small and Medium Administration, Ministry of Economic Affairs, Taiwan. 


\subsection{Observation No. 5}

The net operating profit of SMEs (4.79 p) as compared to large corporations is lower than large corporations (5.19 p) in 2012 (Table 2) and only 23\% of SMEs survive for more than 20 years as compared to 38\% for large corporations in 2012 (Table 3). The "planning to expand" depicts SMEs as less willing to expand their business (15.56 p) in the future as compared to large corporations (21.92 p) in 2012 (Table 4). Taiwanese SMEs are still dominated by the manufacturing sector (38.44\% of sales are generated by manufacturing firms while $36.39 \%$ of

Table 2. Profit and loss of Taiwanese enterprises (2009-2011). Unit: \%.

\begin{tabular}{|c|c|c|c|c|c|c|}
\hline \multirow{2}{*}{ Size/year } & \multicolumn{3}{|c|}{ SMEs } & \multicolumn{3}{|c|}{ Large enterprises } \\
\hline & 2009 & 2010 & 2011 & 2009 & 2010 & 2011 \\
\hline Net operating income & 100.00 & 100.00 & 100.00 & 100.00 & 100.00 & 100.00 \\
\hline Less: operating costs & 80.98 & 80.88 & 78.41 & 91.79 & 89.71 & 87.48 \\
\hline Gross operating profit & 19.02 & 19.12 & 21.59 & 8.21 & 10.29 & 12.52 \\
\hline Less: operating expenses & 18.43 & 16.97 & 16.80 & 6.39 & 6.40 & 7.34 \\
\hline Net operating profit & 0.59 & 2.14 & 4.79 & 1.82 & 3.89 & 5.19 \\
\hline
\end{tabular}

Source: White paper on SMEs 2012 issued by small and medium administration, Ministry of Economic Affairs, Taiwan.

Table 3. Taiwan SMEs survival years ratio (2008-2012). Units: enterprises: \%.

\begin{tabular}{|c|c|c|c|c|c|c|}
\hline \multirow[b]{2}{*}{ Age } & \multirow{2}{*}{2008} & \multirow{2}{*}{2009} & \multirow{2}{*}{2010} & \multirow{2}{*}{2011} & \multicolumn{2}{|c|}{2012} \\
\hline & & & & & SMEs & Large enterprises \\
\hline Total no. of SMEs & $1,234,739$ & 132,025 & $1,247,998$ & $1,279,784$ & $1,306,729$ & 31,161 \\
\hline Less than 1 year & 6.99 & 7.19 & 7.50 & 7.78 & 7.34 & 0.64 \\
\hline 1 - 2 years & 7.25 & 6.76 & 6.95 & 7.20 & 7.44 & 1.99 \\
\hline 2 - 3 years & 7.34 & 6.16 & 5.75 & 5.88 & 6.15 & 2.43 \\
\hline 3 - 4 years & 7.08 & 6.45 & 5.38 & 5.04 & 5.14 & 2.89 \\
\hline $4-5$ years & 5.61 & 6.33 & 5.75 & 4.79 & 4.51 & 2.71 \\
\hline 5 - 10 years & 20.64 & 21.01 & 21.95 & 22.30 & 21.53 & 17.57 \\
\hline 10 - 20 years & 24.63 & 25.10 & 25.33 & 25.05 & 24.93 & 34.01 \\
\hline Over 20 years & 20.47 & 21.02 & 21.39 & 21.96 & 22.95 & 37.76 \\
\hline
\end{tabular}

Source of ministry of finance tax data center, VAT data for 2008-2012.

Table 4. Taiwan SMEs planning to expand operations ratio (2011-2012).

\begin{tabular}{|c|c|c|c|c|c|c|c|c|}
\hline \multirow{2}{*}{$\begin{array}{l}\text { Enterprises/year } \\
\text { item }\end{array}$} & \multicolumn{2}{|c|}{ All enterprises } & \multicolumn{2}{|c|}{ Large enterprises } & \multicolumn{2}{|c|}{ Medium-sized enterprises } & \multicolumn{2}{|c|}{ Small enterprises } \\
\hline & 2011 & 2012 & 2011 & 2012 & 2011 & 2012 & 2011 & 2012 \\
\hline $\begin{array}{l}\text { Planning to expand } \\
\text { scale of operations }\end{array}$ & 18.05 & 15.17 & 32.21 & 21.92 & 20.04 & 15.56 & 10.33 & 8.86 \\
\hline $\begin{array}{l}\text { Planning to maintain } \\
\text { current scale of operations }\end{array}$ & 78.43 & 81.02 & 66.71 & 76.34 & 78.17 & 80.46 & 84.44 & 85.55 \\
\hline $\begin{array}{c}\text { Planning to reduce scale } \\
\text { of operations }\end{array}$ & 3.52 & 3.81 & 1.08 & 1.75 & 1.78 & 3.97 & 5.23 & 5.60 \\
\hline
\end{tabular}

Source of ministry of finance tax data center, VAT data for 2008-2012. 
sales are generated by the wholesale and retailing sector in 2012). It is interesting to note that wholesale and retailing is the major GDP generator of the Taiwanese service industry (19.31\%) in 2012. It is astonishing to see that a major portion of wealth creation through GDP is done by large corporations ( $63 \%$ of wholesale sales confirmed this evidence) [56].

\subsection{Discussion}

This research concludes that there is definitely a relationship between entrepreneurship and the economic development of Taiwan considering that fact that SMEs contribute to the absorption of human resources and produce competition in the market, but it is also a fact that SMEs are not capable of producing a substantial economic impact on the future economic development of Taiwan. This research was based on the assumption that entrepreneurship plays a substantial role in the present economic development of Taiwan. But, this assumption was partially verified and partially falsified by the data gathered by the researcher during this research; he found that there is a relationship between entrepreneurship and economic development but the relationship is quite weak rather than strong as previously assumed by the researcher. As research found enough theoretical evidence to prove the relationship between each independent and dependent variable by using Nvivo 10 computer software. Firstly, the relationship between non-technical innovations in terms of entrepreneurship with economic development can also be exemplified by following data gathered. "Entrepreneurship can contribute in important ways to economic development. One way it does this is through innovation, which involves the development of new products, new processes, new sources of supply, but also the exploitation of new markets and the development of new ways to organize business [57]." "It can be inferred from the preceding research on non-technical innovation that Taiwan's success and economic development in the last six to seven (1940-2014) decades is not because of only technical innovation but also non-technical innovation like the transaction costs among organizations that contributed a very significant role in the profit-cost nexus among small SMEs in Taiwan. Governance of economic exchange or transactions is at the core of the growth and development of the economy. Sharing similar intellectual heritages, transaction cost economics (TCE) and new institutional economics (NIE) both seek to understand how exchange is conducted. An economy can be conceptualized as a range of organizations, within each and between each there are a nexus of transaction [58].

The researcher further found that there is a huge amount of data available to explore the relationship between human resource productivity and the economic development of Taiwan as this is reinforced by the following literature. Solow (1956) argues that "human resource productivity is the most important determinant influencing the nation's level of income [10]." Meanwhile, according to Englander and Gurney (1994), "low labour productivity will be a barrier to income increment rate and can also increase the incidence of conflicts in income distribution [59].” Education levels are linked to productivity growth, as argued in Schultz (1975), Welch (1975), Benhabib and Spiegal (1992). "In general, an educated, motivated and flexible labour force will be able to adapt more easily to new processes and new industries, and hence allow productivity to rise more rapidly [60]-[62]. Where the average level of human capital is high, the incidence of learning from others will be higher, and it is likely that there will be greater productivity gains to be derived from exchanging ideas [63].”

Subsequently, the researcher investigated that there is a relationship between government policies regarding SMEs and the economic development of Taiwan by considering the following evidence from the literature: "small and medium enterprises have a more significant role in improving economic growth and industrial development of nations by contributing to the creation of employment, income generation opportunities and wealth, promotion of entrepreneurship and enhancing of exports [64].” The literature existing on SMEs shows that government policies on the development of SMEs and economic growth are positively related with each other. Therefore, policies to promote the development of SMEs are common in both developed and developing countries [65][67]. Government policy should be directed at establishing a level playing field for SME development and operation [54].

The following statement was concluded based on the qualitative data analysis and the observations made during analyzing quantitative data.

The results can be illustrated as following Figure 7.

\subsection{Recommendations for Future Research}

This research only covers three components of entrepreneurship and their impact and role in the future economic 


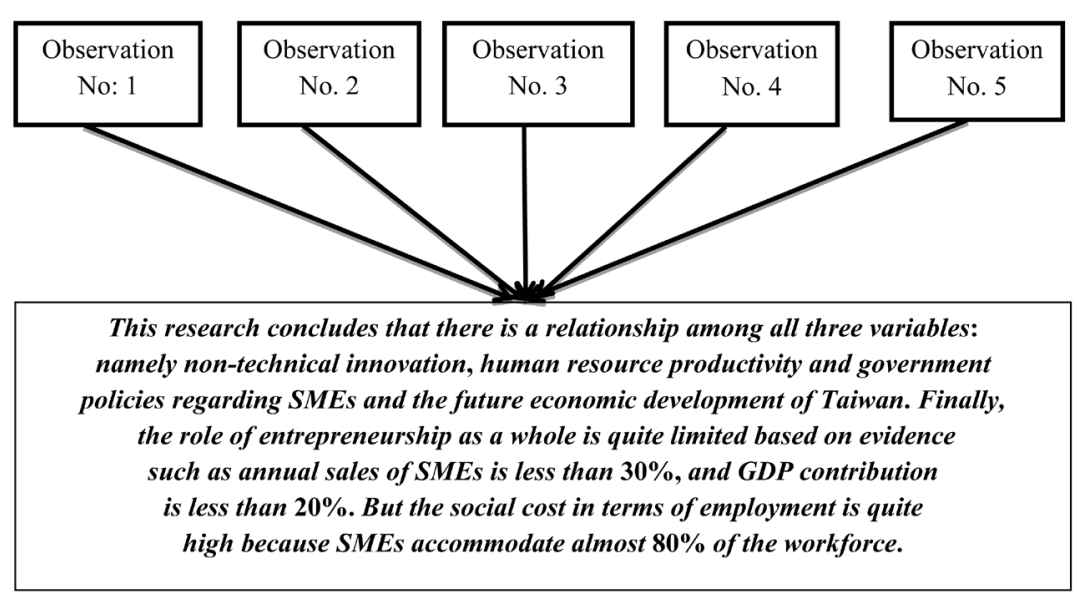

Figure 7. Conclusive statement of this research.

development of Taiwan. There could be more components that are not covered by this research, like culture, non-technical and technical education, and financial institutions supporting SMEs in Taiwan. Other areas of study might be E-entrepreneurship and its role in economic development, or comparison of growth and development of SMEs with large corporations of Taiwan.

\section{References}

[1] Asia Productivity Organization Report (2015) Innovation and SME Financing in Selected Asian Economies, Tokyo.

[2] Veselka, M. (2005) Taiwan's Economic Development: The Role of Small and Medium-Sized Enterprises beyond the Statistics. Paper Presented at the Second Conference of the European Association of Taiwan Studies, Ruhr University Bochum, Germany, 1-2 April. http://dx.doi.org/10.2139/ssrn.872387

[3] Lima, J.M.D.C. (2008) Patterns of Internationalization for Developing Country Enterprises (Alliances and Joint Ventures). Prepared for UNIDO (United Nations Industrial Development Organization), Wien, 2008.

[4] Global Competitiveness Report (2013) Issued by World Economic Forum, Geneva.

[5] Sanyang, S.E. and Huang, W.C. (2008) Small and Medium Enterprise for Women Entrepreneurs in Taiwan. World Journal of Agricultural Sciences, 4, 884-890.

[6] Goldsmith, P. (2000) What Is Entrepreneurship? University of Illinois Extension.

[7] Ahmad, N. and Seymour, R.G. (2008) Defining Entrepreneurial Activity: Definitions Supporting Frameworks for Data Collection OECD Statistics Working Paper, 5-6.

[8] Kenney, M., Han, K. and Tanaka, S. (2002) The Globalization of Venture Capital: The Cases of Taiwan and Japan.

[9] Wu, R.I. and Huang, C.C. (2003) Entrepreneurship in Taiwan: Turning Point to Restart: 1, 5-6 Mansfield Foundation.

[10] Solow, R.M. (1956) A Contribution to the Theory of Economic Growth. Quarterly Journal of Economics, 70, 65-94. http://dx.doi.org/10.2307/1884513

[11] Rautakivi, T. (2012) Impact of Foreign Direct Investment (FDI) on Economic Growth in Asia’s Newly Industrialized Countries. Burapha University, Bangsaen.

[12] Coleman, D. and Nixon, F. (1985) Economics of Change in Less Developing Countries. Philip Allen, Oxford.

[13] OECD (2008) OECD Insights Sustainable Development Linking Economy, Society, Environment. OECD Rights and Translation Unit (PAC) 2 rue André-Pascal, 75116 Paris, France.

[14] Strange, T. and Bayley, A. (2008) OECD Insights Sustainable Development Linking Economy, Society, Environment. OECD Report, Geneva.

[15] Huntington, S.P. (1968) Political Order in Changing Societies. Yale University Press, New Haven.

[16] Todaro, M.P. and Smith, S.C. (2004) Economic Development. 8th Edition, Longman Publication, New York, 110.

[17] Rigger, S. (2011) Why Taiwan Matters—Small Island, Global Powerhouse. Rowman \& Littlefield Publishers, New York, 59-94.

[18] Meltzer, J. (2014) Taiwan's Economic Opportunities and Challenges and the Importance of the Trans-Pacific Partnership. East Asia Policy Paper Series, Washington DC. 
[19] Coase, R.H. (1937) The Nature of the Firm. In: Williamson, O. and Winter, S., Eds., The Nature of the Firm: Origins, Evolution and Development, Oxford University Press, New York, 18-33.

[20] Ranis, G. (2008) Taiwan’s Success and Vulnerability. Routledge, Abingdon and New York.

[21] McCann, L., Colby, B., Easter, K.W., Kasterine, A. and Kuperan, K.V. (2005) Transaction Costs Measurement for Evaluating Environmental Policies. Ecological Economics, 52, 527-542. http://dx.doi.org/10.1016/j.ecolecon.2004.08.002

[22] Globerman, S. and Schwindt, R. (1986) The Organization of Vertically Related Transaction in the Canadian Forest Products Industries. Journal of Economic Behavior \& Organization, 7, 199-212. http://dx.doi.org/10.1016/0167-2681(86)90005-3

[23] Pittman, R. (1991) Specific Investments, Contracts, and Opportunism: The Evolution of Railroad Sidetracks Agreements. The Journal of Law and Economics, 34, 565-589. http://dx.doi.org/10.1086/467236

[24] Leffler, K.B. and Rucker, R.R. (1991) Transaction Costs and the Efficient Organization of Production: A Study of Timber-Harvesting Contracts. Journal of Political Economy, 99, 1060-1087. http://dx.doi.org/10.1086/261789

[25] Lyons, B.R. (1994) Contracts and Specific Investment: An Empirical Test of Transaction Theory. Journal of Economics Management Strategy, 3, 257-278. http://dx.doi.org/10.1111/j.1430-9134.1994.00257.x

[26] Moss, L.E., Barry, P.J., Schnitkey, G.D. and Westgren, R.E. (2001) A Transaction Cost Economics and Property Rights Theory Approach to Farmland Lease Preferences. Proceedings of the AAEA Annual Meeting, Chicago, 5-8 August 2001.

[27] Riegl, M.M. (2014) Prospects and Limits of Economic Development of Unrecognized States: Between Organized Hypocrisy and Private Interests. Department of Political Science, Institute of Political Studies, Faculty of Social Sciences, Charles University in Prague, Prague.

[28] Pegg, J. (1998) De Facto States in the International System Institute of International Relations. University of British Columbia Working Paper, No. 21, February 1998.

[29] Ministry of Economic Affairs, MOEA (2014) Small and Medium Enterprise Administration. http://www.moeasmea.gov.tw/ct.asp?xItem=72\&CtNode=263\&mp=2

[30] Trochim, W.M.K. (2002) The Research Methods Knowledge Base. 2nd Edition, Cornell University, New York.

[31] Kothari, C.R. (1985) Research Methodology_Methods and Techniques. Wiley Eastern Limited, New Delhi.

[32] Kirzner, I.M. (1973) Competition and Entrepreneurship. University of Chicago Press, Chicago.

[33] Porter, M.E. (1990) The Competitive Advantage of Nations. Competitive Intelligence Review, 1, 14. http://dx.doi.org/10.1002/cir.3880010112

[34] Lin, H.F. (2007) Knowledge Sharing and Firm Innovation Capability: An Empirical Study. International Journal of Manpower, 28, 315-332. http://dx.doi.org/10.1108/01437720710755272

[35] Wu, Y.L. (2009) The Analysis of Innovation Efficiency and Non-Technological Factors of Manufactory Companies in the Pearl River Delta of China. The Center for Applied Statistics, Renmin University of China, Beijing.

[36] Baranano, A.M. (2003) The Non-Technological Side of Technological Innovation: State of the Art and Guidelines for Further Empirical Research. International Journal of Entrepreneurship and Innovation Management, 3, 107-125. http://dx.doi.org/10.1504/IJEIM.2003.002223

[37] Boer, H. and During, W.E. (2001) Innovation, What Innovation? A Comparison between Product, Process and Organizational Innovation. International Journal of Technology Management, 22, 83-107. http://dx.doi.org/10.1504/IJTM.2001.002956

[38] OECD (2005) Oslo Manual. Guidelines for Collecting and Interpreting Innovation Data. 3rd Edition, Geneva, $172-182$.

[39] Afuah, A. (1998) Innovation Management: Strategies, Implementation and Profits. Oxford University Press, New York.

[40] Acs, Z.J. and Audretsch, D.B. (1990) Innovation and Small Firms. The MIT Press, Cambridge.

[41] Dodgson, M. (1993) Technological Collaboration in Industry: Strategy, Policy and Internationalization in Innovation. Routledge Publication, London.

[42] Becker, G.S. (1964) Human Capital. University of Chicago Press, Chicago.

[43] Silva, S.D. (1997) Human Resource Development for Competitiveness: A Priority for Employers. International Labour Office, Geneva.

[44] Mann, D., Lee, E., Ng, J., Henderson, C. and Devesh, D. (2014) Asia Productivity Report. FICC Research Standard Chartered Bank, Singapore.

[45] Ministry of Education (2011) Ministry of Education Report: Technological and Vocational Education in Taiwan. Min- 
istry of Education, Taipei City.

[46] World Bank (1994) World Bank Report: Infrastructure for Development. Geneva.

[47] World Bank (2002) World Bank Report: Building Institutions for Markets. Geneva.

[48] World Bank (2004) World Bank Report: World Bank Report Making Services Work for Poor People. Geneva.

[49] YES SME Publication (2012) Role of the Government in SME Financing, India.

[50] Pereira, C. and Romero, F. (2013) Non-Technological Innovation Current Issues and Perspectives. Production and Systems Department, School of Engineering University of Minho, Portugal.

[51] International Labor Organization (2008) Skills for Improved Productivity, Employment Growth and Development. ILO, Geneva.

[52] Chen, H.C. (2003) Cross Cultural Construct Validation of the Learning Transfer System Inventory in Taiwan. The School of Human Resource Education and Workforce Development, Louisiana State University, Baton Rouge.

[53] Fields, G.S. (1992) Living Standards, Labor Markets and Human Resources in Taiwan. Cornell University, New York.

[54] Ministry of Foreign Affairs (MOFA) of Japan (2014) Policies to Support Small and Medium Sized Enterprises (SMEs) for Economic Development. http://www.mofa.go.jp/region/latin/fealac/sme.html

[55] Stevenson, L. and Lundstrom, A. (2001) Patterns and Trends in Entrepreneurship/SME Policy and Practice in Ten Economies. Volume 3 of the Entrepreneurship Policy for the Future Series, Swedish Foundation for Small Business Research and Supported by the Swedish Ministry of Industry, Employment and Communications, NUTEK, and Örebro University in Sweden.

[56] White Paper on SMEs (2012) Small and Medium Enterprise Administration. Small and Medium Enterprise Administration, Ministry of Economic Affairs, Taipei, 106.

[57] Szirmai, A., Naude, W. and Goedhuys, M. (2011) Entrepreneurship, Innovation, and Economic Development. Oxford University Press, New York. http://dx.doi.org/10.1093/acprof:oso/9780199596515.001.0001

[58] Maitland, E., Nicholas, S. and Boyce, G. (2009) The Economics of Governance: Transaction Cost Economics and New Institutional Economics. Australian School of Business, UNSW, Faculty of Business and Law University of Newcastle, Australia.

[59] Englander, S. and Gurney, A. (1994) OECD Productivity Growth: Medium-Term Trends. OECD Economics Studies, 22, 111-129.

[60] Schultz, T.W. (1961) Investment in Human Capital. American Economic Review, 51, 1-17.

[61] Welch, F. (1975) Education in Production. Journal of Political Economy, 78, 35-59.

[62] Benhabib, J. and Spiegel, M.M. (1992) The Role of Human Capital in Economic Development: Evidence from Aggregate Cross-Country and Regional US. Department of Economics, New York University, New York.

[63] Lucas, R. (1988) On the Mechanics of Economic Development. Journal of Monetary Economics, 22, 3-42.

[64] Mutambi, J., Byaruhanga, J.K., Trojer, L. and Buhwezi, K.B. (2010) Research on the State of Business Incubation Systems in Different Countries: Lessons for Uganda. African Journal of Science, Technology, Innovation \& Development, 2, 190-214.

[65] Storey, D.J. (1994) Understanding the Small Business Sector. Routledge, London. Technological and Vocational Education in Taiwan (2011) Issued by Ministry of Education, August 2011, Taiwan.

[66] Levitsky, J. (1996) Support Systems for SMEs in Developing Countries: A Review. Paper Commissioned by the Small and Medium Industries Branch, United Nations Industrial Development Organization.

[67] Hallberg, K. (2000) A Market-Oriented Strategy for Small and Medium-Scale Enterprises. Discussion Paper No. 40, International Finance Corporation, the World Bank, Geneva. 